\title{
Genes flow by the channels of culture: the genetic imprint of matrilocality in Ngazidja, Comoros Islands
}

\author{
Stéphane Mazières ${ }^{1} \cdot$ Pauline Oviedo $^{1} \cdot$ Célia Kamel $^{1} \cdot$ Pascal Bailly $^{1,2} \cdot$ Caroline Costedoat $^{1} \cdot$ Jacques Chiaroni ${ }^{1,2}$
}

Received: 22 September 2017 / Revised: 22 March 2018 / Accepted: 27 March 2018 / Published online: 30 April 2018

(c) The Author(s) 2018. This article is published with open access

\begin{abstract}
Post-marital residence of spouses is one of the architects of population genetic structure. In the present study, we tested how the place of residence of males and females in Ngazidja, Comoros Islands, has unequally channeled, by dispersal among villages, the male and female genetic diversity. Using sequences of the hypervariable segment I of the mitochondrial DNA (mtDNA HVS-I) and six Y-chromosome microsatellites (Y-STRs), we measured the genetic variation and male-to-female effective number of migrants ratios based on $F_{\mathrm{ST}}$ values and revealed a genetic structure mostly driven by male gene flow across villages. This genetic feature illustrates the uxori-matrilocality inherited from the Bantu expansion, though one exception exists in Bandamadji whose historically documented military status implied patrilocality in this locality.
\end{abstract}

\section{Introduction}

The Comoros Islands are an archipelago of four islands, Ngazidja (Great Comoros in the Shingazidja dialect), Nzduani (Anjouan in Shindzuani), Mwali (Mohéli in Shimwali), and Mahore (Mayotte in Shimaore), located at the northern end of the Mozambique Channel in the Indian Ocean. Historical, social, linguistic, and genetic studies showed that the Comorian population arose from the encounter of East African Bantu metallurgists with Islamic Middle Eastern traders and, to a lesser degree, with Austronesian people [1-5].

The social structure in Comoros Islands results from the interactions between Islam's laws and ancestral rites from East Africa, with a mixed distribution of matrilineal and patrilineal traits in various domains of social organization: kinship, inheritance of property, succession to titles, mode of residence, and detention of authority $[2,6]$. In the four islands,

Electronic supplementary material The online version of this article (https://doi.org/10.1038/s41431-018-0154-y) contains supplementary material, which is available to authorized users.

Stéphane Mazières

stephane.mazieres@univ-amu.fr

1 Aix Marseille Univ, CNRS, EFS, ADES, Marseille, France

2 Etablissement Français du Sang PACA Corse, Biologie des groupes sanguins, Marseille, France the post-marital residence is largely uxori-matri-local: the husband resides with his wife and the daughters marry in the place of residence of their mother $[2,6]$. Under African costumes and Islam's laws, men are allowed to practice polygyny [2]. However, in order to rise its social position, a man has to realize his "great marriage" with a woman from his own village. This specific union happens while he is able to assume the great expenses needed for this unique event and during his adult's life. Before, he may or has to conclude other unions that are not necessarily with women from his own maternal village, called "little marriage". Men are thus considered as "itinerant" husbands moving from one to other village and will have between two to five unions in their life. Meanwhile, for her wedding the bride is given a house from her mother's family. The oldest maternal uncle looks after her education and the one of her children, but these rules are not applied if the woman leaves the village. Furthermore, each Comorian individual and its social rights are as a priority identified by his matriclan, called hinya. All these conditions create a real socio-economic pressure to stay in the birth village for both men and women $[2,6]$.

Previous surveys in matrilocal and patrilocal structured populations have shown a contrasted pattern of within and between-population genetic variation when examined for paternally and maternally inherited genetic markers [7, 8]. Herein, we explored the uniparental genetic variation between five villages of the Great Comoros Island, Ngazidja, and tested to what extent the "little marriages" strengthened by the 
Table 1 Summary statistics of mtDNA and Y-STRs genetic variation within and between five villages of Ngazidja

\begin{tabular}{|c|c|c|c|c|c|c|c|}
\hline $\begin{array}{l}\text { Genetic } \\
\text { marker }\end{array}$ & Estimator & Bandamadji & Hahaya & Iconi & Male & Mitsoudje & Ngazidja \\
\hline & Number of inhabitants & 2000 & 2600 & 8000 & 13,000 & 5000 & \\
\hline \multirow[t]{8}{*}{ mtDNA } & Sample size & 11 & 20 & 17 & 18 & 11 & 77 \\
\hline & Genetic diversity & 0.946 & 0.742 & 0.985 & 0.699 & 0.927 & 0.864 \\
\hline & $\mathrm{Pw}$ & 10.1 & 4.3 & 10.8 & 10.4 & 10.8 & \\
\hline & $\begin{array}{l}\text { Mean } F_{\mathrm{ST}} \text { ( } p \text {-value) with } \\
\text { the other villages }\end{array}$ & $\begin{array}{l}0.108 \\
(0.205)\end{array}$ & $\begin{array}{l}0.220 \\
(0.000)\end{array}$ & $\begin{array}{l}0.071 \\
(0.164)\end{array}$ & $\begin{array}{l}0.150 \\
(0.016)\end{array}$ & $\begin{array}{l}0.098 \\
(0.088)\end{array}$ & \\
\hline & PS & 0.73 & 0.20 & 0.76 & 0.33 & 0.55 & \\
\hline & $\mathrm{C}$ & 1.22 & 2.50 & 1.13 & 2.25 & 1.38 & \\
\hline & $\begin{array}{l}\% \text { of variation among } \\
\text { population }\end{array}$ & & & & & & $\begin{array}{l}15.32 \\
(0.000)\end{array}$ \\
\hline & $\begin{array}{l}\% \text { of variation within } \\
\text { population }\end{array}$ & & & & & & $\begin{array}{l}84.68 \\
(0.000)\end{array}$ \\
\hline \multirow[t]{9}{*}{ Y-STRs } & Sample size & 9 & 16 & 22 & 22 & 17 & 86 \\
\hline & Genetic diversity & 0.722 & 0.942 & 0.952 & 0.987 & 0.971 & 0.953 \\
\hline & $\mathrm{Pw}$ & 2.3 & 3.3 & 3.7 & 3.6 & 3.5 & \\
\hline & $\begin{array}{l}\text { Mean } R_{\mathrm{ST}} \text { ( } p \text {-value) with } \\
\text { the other villages }\end{array}$ & $\begin{array}{l}0.114 \\
(0.036)\end{array}$ & $\begin{array}{l}0.043 \\
(0.110)\end{array}$ & $\begin{array}{l}0.018 \\
(0.279)\end{array}$ & $\begin{array}{l}0.062 \\
(0.216)\end{array}$ & $\begin{array}{l}0.032 \\
(0.340)\end{array}$ & \\
\hline & PS & 0.44 & 0.31 & 0.68 & 0.73 & 0.71 & \\
\hline & $\mathrm{C}$ & 1.80 & 1.60 & 1.29 & 1.16 & 1.21 & \\
\hline & $\begin{array}{l}\% \text { of variation among } \\
\text { population }\end{array}$ & & & & & & $\begin{array}{l}4.74 \\
(0.000)\end{array}$ \\
\hline & $\begin{array}{l}\% \text { of variation within } \\
\text { population }\end{array}$ & & & & & & $\begin{array}{l}95.26 \\
(0.000)\end{array}$ \\
\hline & $\begin{array}{l}\text { Mean male-to-female } \\
\text { number of migrants ratio }\end{array}$ & 0.9 & 7.1 & 7.0 & 2.6 & 3.3 & 3.6 \\
\hline
\end{tabular}

Values in the Ngazidja column were obtained from the AMOVA. Male-to-female number of migrants ratio was inferred from [15]

$P w$ mean number of pairwise differences, $P S$ proportion of haplotypes observed only once in the population, $C$ mean number of individuals carrying the same haplotype

matrilocal and matrilineal social organization has left footprints in the genetic structure of this population.

\section{Material and methods}

In accordance with French regulations of an ethical committee (Ministry of Research, record number DC-2008-164 and amendments, formally approved on December 15th, 2008), we collected with consent approval 86 male samples from five villages of Ngazidja: Bandamadji, Hahaya, Iconi, Male, and Mitsoudje. We included only unrelated men for at least two generations back in time and ensured the name of their birth village.

Blood collection and lab methods are detailed in ref. [9]. DNAs were sequenced for mtDNA HVS-I (GenBank accession numbers: MG878303-MG878379) and aligned to the Cambridge Reference Sequence [10], then screened for Y-STRs with the AmpFLSTR ${ }^{\text {TM }}$ YfilerTM PCR Amplifica- $^{\text {TM }}$ tion Kit (Applied Biosystem). Six of them (DYS389I,
DYS389II, DYS390, DYS391, DYS392, and DYS393) were retained given their usefulness in genetic diversity estimates [11] (Table S1).

We first estimated the within-village genetic diversity and pairwise-difference $(\mathrm{Pw})$, then tested the inter-village genetic structure with a measure of $F_{\mathrm{ST}}$ and $R_{\mathrm{ST}}$ genetic distances and distribution of the molecular variance (AMOVA) using the ARLEQUIN software [12]. We also performed two median joining networks using the program NETWORK 4.6.1.1 (Fluxus-Engineering) where we considered the HVS-I poly-C region according to ref. [13] and weighted the Y-STRs loci as a function of their variance [14] after exclusion of DYS389I-II as recommended. Lastly, we measured $N_{\text {male }} m_{\text {male }} / N_{\text {female }} m_{\text {female }}$ from $F_{\mathrm{ST}}$ values, the ratio between effective numbers of male and female migrants per generation, as described in ref. [15]. In this approach based on an island model, populations are stable, mutation is negligible and allele frequencies are assumed to result mainly from differences in migration rate per generation $(m)$ and/or effective population size $(\mathrm{N})$. 
a)

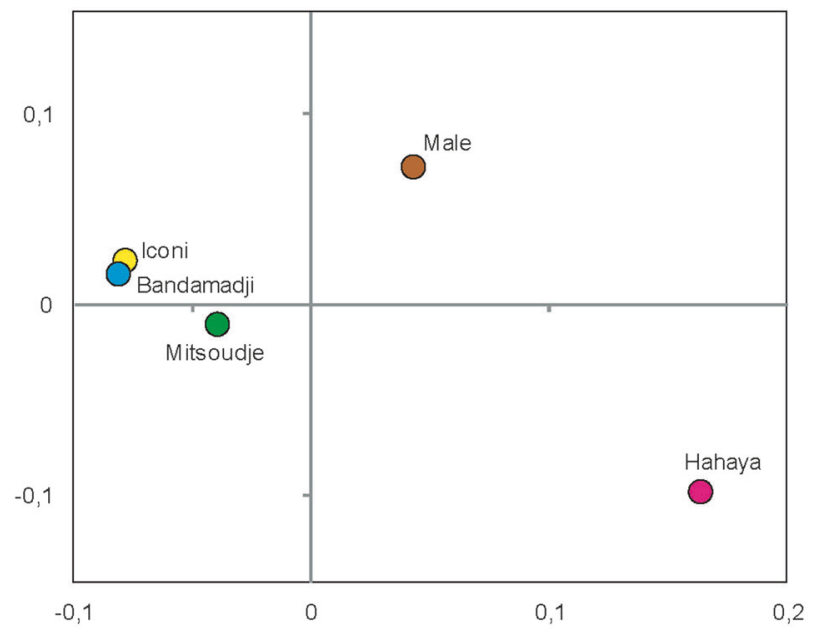

c)

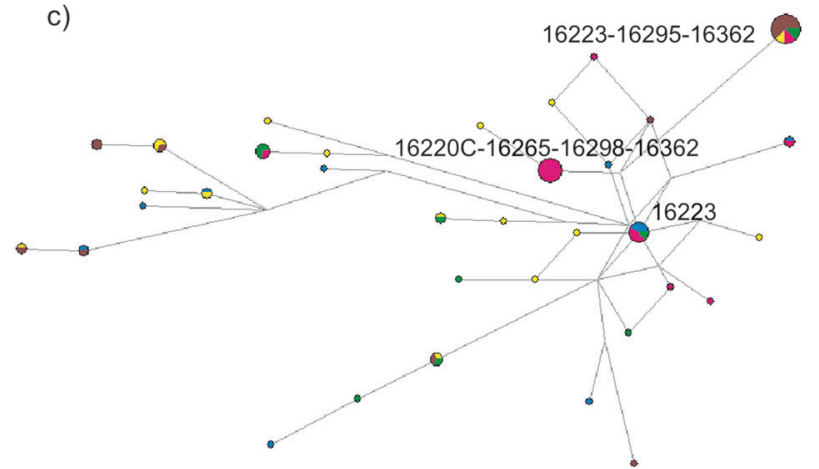

b)

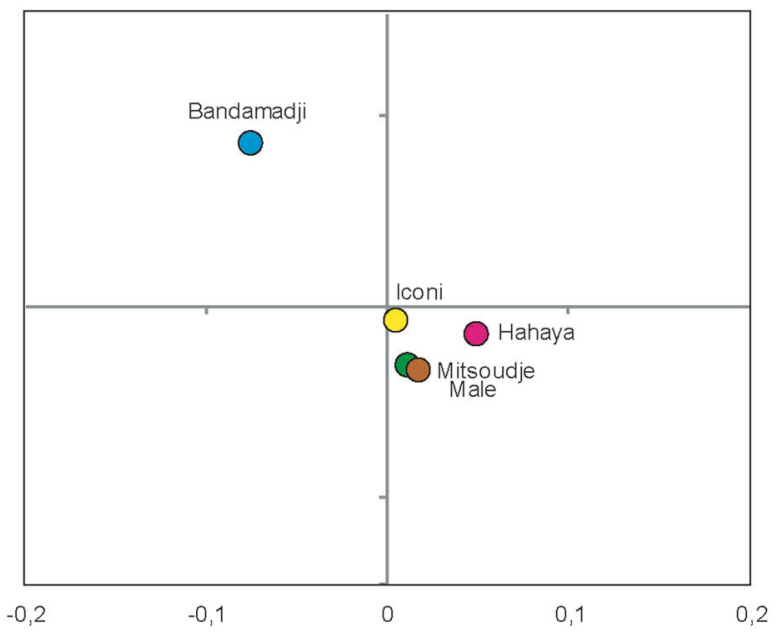

d)

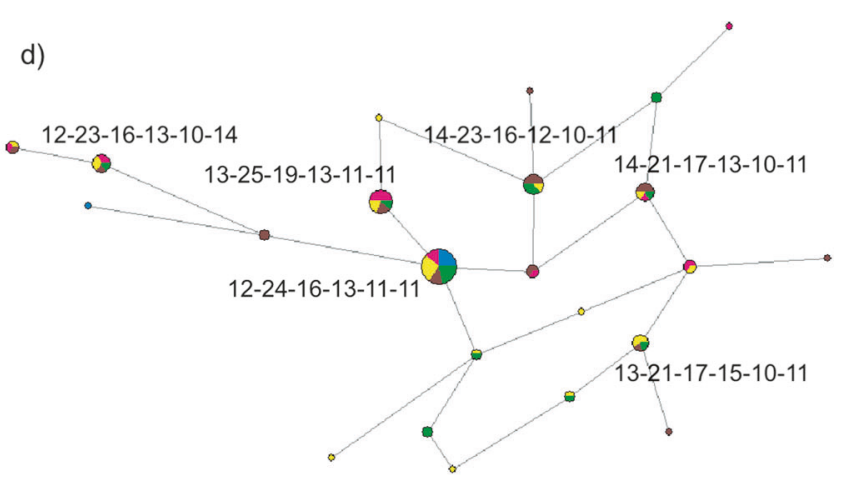

Iconi Male $\bigcirc$ mitsoudje

Fig. 1 Multidimensional Scaling of $F_{\mathrm{ST}}$ for mtDNA HVS-I (a) and $R_{\mathrm{ST}}$ for Y-STRs (b) genetic distances and networks (NETWORK 5.0) of mtDNA HVS-I (c) and Y-STRs (d) haplotypes

Hence, the expected value of genetic differences between populations, $F_{\mathrm{ST}}$, could be written were $F_{\mathrm{ST}}=1 /(1+N m)$ for haploid systems [15].

\section{Results}

We measured the female and male genetic diversity indices in the five Comoros villages understudy (Table 1). The main pattern is a higher male than female genetic diversity as observed in Hayaya, Male, and Mistoudje. Exceptions are Iconi which shows similar values for both uniparental markers, and overall Bandamadji which distinguishes with a higher mtDNA than Y-STRs genetic diversity.

We then depicted the $F_{\mathrm{ST}}$ and $R_{\mathrm{ST}}$ genetic distances onto a Multi Dimensional Scaling (MDS, Fig. 1a, b). For HVS-I, genetic similarities link the Iconi with Bandamadji while Hayaya and Male stand at peripheral positions. As far as the Y-STRs genetic variation is concerned, the Bandamadji village departs strongly from the four remaining villages, separated with non-significant $R_{\mathrm{ST}}$ values. When compared on a haplotype basis (Fig. 1c, d), networks mirror the genetic diversity pattern, as shown in Table 1. Iconi, Mitsoudje, and Bandamadji encapsulate the highest HVS-I haplotype diversity with numerous branches, while most of the Hayaya and Male mtDNAs are included into one main profile. As far as Y-STRs are concerned, every village is spread over the nodes, but Bandamadji which is represented by almost exclusively one profile. Networks also depict higher pairwise differences $(\mathrm{Pw})$ for HVS-I than for $\mathrm{Y}$ STRs (mean $\mathrm{Pw}_{\text {HVS-I }}=9.3$, mean Pw $_{\text {YSTRs }}=3.3$, Mann-Whitney U-test, $p$-value $=0.037)$. Finally, one can notice twice more village-specific haplotypes for HVS-I ( $n$ $=24)$ than for Y-STRs $(n=12)$.

AMOVA points out that HVS-I presents 3.2-times more genetic variation amongst villages than Y-STRs (Table 1, respectively $15.32 \%$ and $4.74 \%, p$-value $=0.000$ ), but less within-village variation (ratio of 0.9 , respectively $84.68 \%$ 


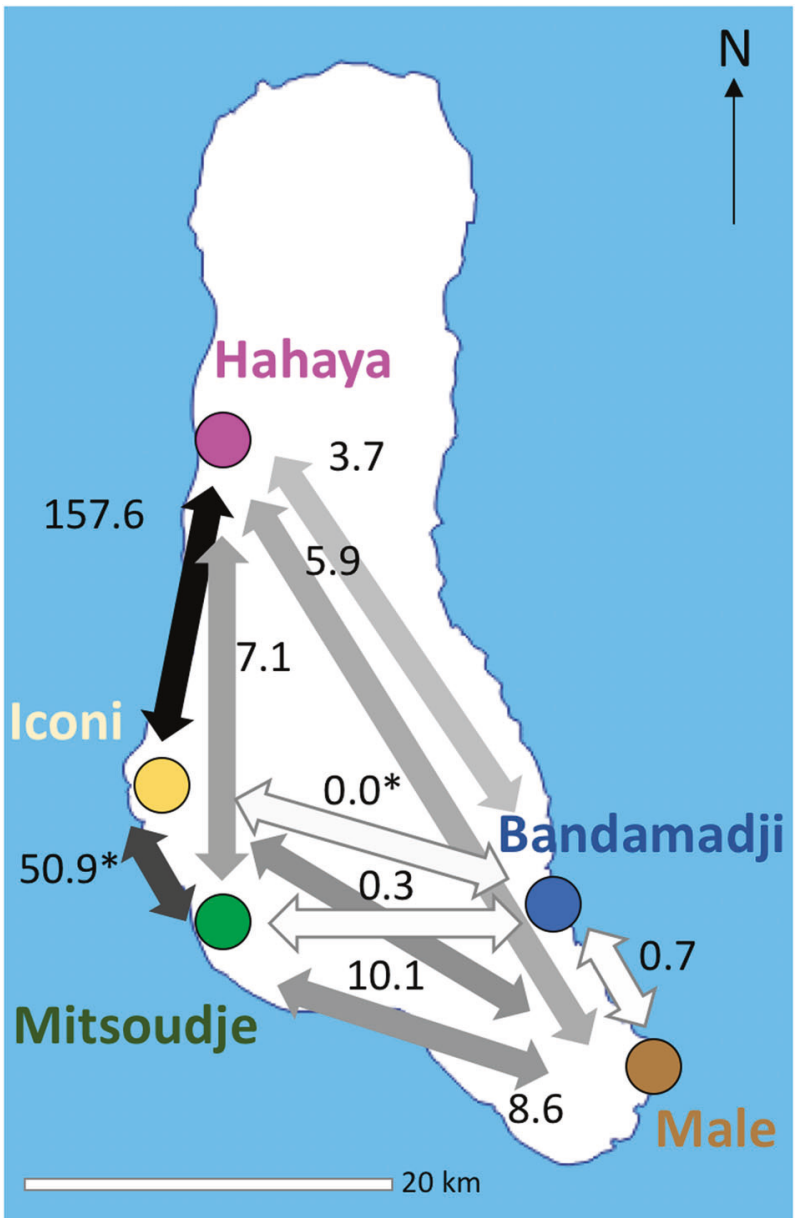

Fig. 2 Intensity of male-to-female number of migrants ratio amongst the five villages understudy. Gray scale is proportional to $\log _{10}\left(F_{\mathrm{ST}}\right.$, ratio) from light (ratio $<1$, i.e., male $<$ female) to dark (ratio $>1$, i.e., male $>$ female). *Drawn from negative $F_{\mathrm{ST}}$ which were considered as 0.001. Background map was taken from www.d-maps.com®

and $95.26 \%, p$-value $=0.000$ ). Due to the distinct genetic pattern of Bandamadji above-mentioned, we ran an additional AMOVA excluding this village. We noticed a strong increase of the contrasting patterns of within-population and between-population genetic variation as seen from HVS-I and Y-STRs, since the female genetic variation among populations reached almost 10 -fold the male one $(17.08 \%$ and $1.74 \%, p$-value $=0.000$ ).

Lastly, from the $F_{\mathrm{ST}}$ values we inferred the magnitude of male-to-female number of migrants ratio per generation for each village and across villages (Table 1 and Fig. 2). The main pattern in the island is a ratio above 1 (mean ratio $=$ 3.5) where it ranges from 2.6 and 7.1 in four villages: Hayaya, Iconi, Male, and Mitsoudje. Exception is Bandamadji with a ratio of 0.9 . Geographical distances do not account for the male and female genetic dissimilarities (Mantel test: km vs. $\mathrm{R}_{\text {STYSTR }}: r=-0.071, p$-value $=0.533$, $\mathrm{km}$ vs. $\mathrm{F}_{S T \mathrm{mtDNA}}: r=0.5, p$-value $\left.=0.124\right)$.

\section{Discussion}

A great variety of human social organizations defined by rules of marriage, residence, descent and mode of subsistence has been described worldwide [16], which in return can substantially impact the genetic diversity [17]. At the global scale, populations would be genetically more structured for paternally than for maternally inherited markers mirroring migrations of women in her mate's residence and thus patrilocality [8]. Nevertheless, matrilocality rules other societies [18] and in the Indian Ocean, the earliest inhabitants of the Comoros originated from East Africa, as the extension of the matrilineal belt that encompassed Africa Bantu which opens to the east since the 11th century [3].

Uniparental genetic markers in Ngazidja indicate a maleoriented repartition of genetic diversity within and amongst villages, which is in accordance with described matrilocality. However, one exception is Bandamadji which behaves as a patrilocal population. Indeed, oral and historical knowledge evokes that Bandamadji was the military basis of one of the great Comorian clan M'Dombozi, where men have sworn fidelity to their sultan Hachim ben Ahmed (died 1889), and hence, had to stay to protect the city ([19] and Kassim Papa, pers. com.).

Finally, the Comorian villages are organized according to the social space in which males and females participate distinctly [2], and the present data agree with these ethnohistorical records. The present study evidences that amongst and within human populations, genes also flow through the channels dug by culture and social organization. It especially illustrates the positive collaboration between geneticists and anthropologists to search together how distribution maps of biological phenomena and cultural phenomena shed light on each other [20].

Acknowledgements We are grateful to all the people who volunteered to participate in the study. We also thank Yannick Bernardie and Adem Miraoui from the UMR7268 ADES for their help in handling the data, as well as Julie Di Cristofaro from the UMR7268 ADES and Etablissement Français du Sang for her constructive comments. Lastly, we thank Kassim Papa, responsible for preparation of blood-derived products at the EFS Reunion, for helpful insights on village history.

Open Access This article is licensed under a Creative Commons Attribution 4.0 International License, which permits use, sharing, adaptation, distribution and reproduction in any medium or format, as long as you give appropriate credit to the original author(s) and the source, provide a link to the Creative Commons license, and indicate if changes were made. The images or other third party material in this article are included in the article's Creative Commons license, unless indicated otherwise in a credit line to the material. If material is not included in the article's Creative Commons license and your intended use is not permitted by statutory regulation or exceeds the permitted use, you will need to obtain permission directly from the copyright holder. To view a copy of this license, visit http://creativecommons. org/licenses/by/4.0/. 


\section{References}

1. Fontes P, Coudray J, Eberschweiler C, Fontes J-C. Datation et conditions d'occupation du site de Koungou (Ile de Mayotte). Rev d'Archéométrie. 1987;11:77-82.

2. Blanchy S. Famille et parenté dans l'archipel des Comores. J Des Afr. 1992;62:7-53.

3. Allibert C, Vérin P. The early pre-Islamic history of the Comores Islands: links with Madagascar and Africa. In: Reade J editor. The Indian Ocean in Antiquity. London: Kegan Paul International; 1996. p. 461-470.

4. Pauly M. La diffusion de l'islam à Mayotte à l'époque médiévale. Rev Des Arch départementales De Mayotte. 2014;4:63-89.

5. Brucato N, Kusuma P, Beaujard P, Sudoyo H, Cox MP, Ricaut FX. Genomic admixture tracks pulses of economic activity over 2,000 years in the Indian Ocean trading network. Sci Rep. 2017;7:2919.

6. Blanchy S. Maisons des femmes, cités des hommes. Filiation, âge et pouvoir à Ngazidja (Comores). Nanterre: Société d'ethnologie; 2009.

7. Seielstad MT, Minch E, Cavalli-Sforza LL. Genetic evidence for a higher female migration rate in humans. Nat Genet. 1998;20:278-280.

8. Oota H, Settheetham-Ishida W, Tiwawech D, Ishida T, Stoneking M. Human mtDNA and Y-chromosome variation is correlated with matrilocal versus patrilocal residence. Nat Genet. 2001;29:20-21.

9. Msaidie S, Ducourneau A, Boetsch G, et al. Genetic diversity on the Comoros Islands shows early seafaring as major determinant of human biocultural evolution in the Western Indian Ocean. Eur J Hum Genet. 2010;19:89-94.
10. Anderson S, Bankier AT, Barrell BG, et al. Sequence and organization of the human mitochondrial genome. Nature. 1981;290:457-465.

11. Zhivotovsky LA, Underhill PA, Cinnioglu C, et al. The effective mutation rate at $\mathrm{Y}$ chromosome short tandem repeats, with application to human population-divergence time. Am J Hum Genet. 2004;74:50-61.

12. Excoffier L, Laval G, Schneider S. Arlequin (version 3.0): an integrated software package for population genetics data analysis. Evol Bioinf. 2005;1:47-50.

13. Bandelt HJ, Parson W. Consistent treatment of length variants in the human mtDNA control region: a reappraisal. Int J Leg Med. 2008;122:11-21.

14. Qamar R, Ayub Q, Mohyuddin A, et al. Y-chromosomal DNA variation in Pakistan. Am J Hum Genet. 2002;70:1107-1124.

15. Segurel L, Martinez-Cruz B, Quintana-Murci L, et al. Sex-specific genetic structure and social organization in Central Asia: insights from a multi-locus study. PLoS Genet. 2008;4:e1000200.

16. Marlowe F. Paternal investment and the human mating system. Behav Process. 2000;51:45-61.

17. Marchi N, Hegay $T$, Mennecier $P$, et al. Sex-specific genetic diversity is shaped by cultural factors in Inner Asian human populations. Am J Phys Anthropol. 2017;162 :627-640.

18. Jones D. The matrilocal tribe: an organization of demic expansion. Hum Nat. 2011;22:177-200.

19. Martin J. Les débuts du protectorat et la révolte servile de 1891 dans l'île d'Anjouan. Rev Fr d'histoire d'outre- Mer. 1973;60:45-85.

20. Levi-Strauss C. Le regard éloigné. Plon edn, Paris, EDI8: 1983. 